Коломієц Наталія, кандидат філологічних наук, доцент, доцент кафедри української та світової літератур Криворізький державний педагогічний університет

\title{
РЕГІОНАЛЬНІ МАРКЕРИ СУЧАСНОЇ ДИТЯЧОЇ ЛІТЕРАТУРИ КРИВОРІЖЖЯ
}

\begin{abstract}
У статті зроблено спробу дослідити сучасну дитячу літературу Криворіжжя як локально-регіоналъне явище культури. У розвідиі спостережено, що твори для дітей митців краю органічно входять у загалъний простір украӥнсъкоӥ кулътури. Встановлено, що вагому інформаційну роль у текстах відіграють маркери на позначення своєрідності краю (гідроніми, назви корисних копалин, описи ландиафтних особливостей, інформація про металургійно-гірничі професіӥ, знаряддя пращі тощо). У результаті проведеного аналізу визначено, що в основі регіональної ідентичності Криворіжжся лежить погляд на край як один із найпотужніших залізорудних басейнів краӥни. Уведення иих смислових моделей у художній світ дитячих творів сприяе бормуванню у свідомості юних читачів відчуття власноӥ регіоналъної приналежсності.
\end{abstract}

Ключові слова: регіоналізм, дитяча література, регіональна ідентичність, регіонально-локальна специфіка творів.

\begin{abstract}
Kolomiets Nataliia. Regional markers of modern children's of Kryvorizhya.

The article attempts to explore contemporary children's literature of Kryvorizhzhia as a local-regional phenomenon of culture. The works of Inna Dolennik, Nina Yolkina, Mykola Oleksiienko, Ihor Rukavitsyn, Dmitriy Shcherbina and others were analyzed. It is established that the literature for children of preschool and primary school age is represented by the following genres: poems, riddles, fairy tales and stories. Intelligence has observed that works for children of the region are organically included in the common space of Ukrainian culture. They are geared to the needs of diverse reading groups and are designed to help shape one's personality. They have created a specific picture of the artistic world, the dimensions of which are oriented to the peculiarities of children's aesthetic perception.

It is established that markers of regional identity (hydronyms, names of minerals, descriptions of landscape features, information about metallurgical and mining professions, tools, etc.) play a significant informational role in the texts. As a result of the analysis, it is determined that the regional identity of Kryvorizhzhya is based on the view of the region as one of the most powerful iron ore basins of the country. The introduction of these semantic models into the artistic world of children's works contributes to the formation of a sense of regional identity in the minds of young readers.
\end{abstract}


130Літератури світу: поетика, ментальність і духовністъ. 2020. Bип.14

Key words: regionalism, children's literature, regional identity, regional-local specificity of works.

Постановка проблеми. На сучасному етапі простежується тенденція поглибленого вивчення регіональних художніх надбань, які утворюють гіпертекст національної літератури. Як стверджує О.Яковлев, нині відбувається розквіт «регіонального руху, що демонструе різноманітність культурного ландшафту України, мистецьку своєрідність $\dddot{\imath}$ регіонів» [10, с.110]. За таких умов видаються продуктивними різновекторні дослідження творчого життя певного краю. Культурологічний аспект дослідження літератури, що розвивається та функціонує в певному соціокультурному просторі, акцентує увагу на ландшафтно-природних особливостях місцевості, самобутності облаштування побуту, інформації про історичні події тощо. Дослідження літературознавців увиразнюють як регіонально-локальну специфіку мистецтва, так і засвідчують той факт, що художні здобутки майстрів слова різних історико-культурних локацій України відбивають загальний розвій національного письменства. Маркерами регіональної ідентичності у творах виступають різноманітні культурні коди та смисли, що представлені в характеристиці традиційної діяльності мешканців, зображенні територіальних зацікавлень, змалюванні просторової та соціально-економічної організації життя краю тощо. Усі ці ознаки увиразнюють унікальний соціокультурний образ певної місцевості та формують психологічну основу для відчуття єдності спільнотою.

Інтенсивний розвиток сучасної літератури Криворіжжя дозоляє говорити про формування потужного культурного осередку на території України. Із новинками місцевих авторів читачі багато років поспіль знайомляться зі сторінок альманахів «Саксагань», «Символ», літературно-культурологічного часопису «Кур'єр Кривбасу» тощо. Мистецький обрис сучасного міста увиразнюють телевізійні проекти «Книжкова полиця», «КнижКино», «Прості історії, «Ракурс». Ментально-духовний простір регіону формують різноманітні культурологічні проекти (поетично-музичний фестиваль «Руді тексти», бук-проект «Книгосховище.kr», проект «Книгосховище у скрині», фестиваль дитячої книги «Приндик-фест» тощо).

Дитяча література Криворіжжя є органічною частиною локальнорегіонального культурного процесу. Ї̈̈ метасистема репрезентована дитячим фольклором, творами, написаними для дітей, та текстами, авторами яких є діти. Усі ці явища належать до дитячої субкультури, 
орієнтовані на запити різновікових читацьких груп та покликані допомагати формуванню особистості.

Аналіз останніх досліджень і публікацій. Регіоналізм як науковий напрям нині набуває ознак міждисциплінарного дослідження. Осмислення розвитку історико-культурних зон України проводиться в різних аспектах: демографічному, історичному, синергетичному, геополітичному, культурологічному тощо. Розробляючи питання методологї вивчення культури, О.Яковлев серед перспективних напрямів сучасних досліджень визначив «висвітлення закономірностей розвитку культури певного регіону» $[10$, с. 110]. Характеристиці літературно-мистецького життя окремих територіальних спільнот України присвячено значну кількість праць, проте недостатньо вивченою залишається регіональна дитяча література. Серед наукових розвідок, у яких порушено цей аспект, слід назвати монографію Л. Ходанич «Виховний потенціал дитячої літератури Закарпаття». У праці комплексно досліджено художні особливості крайової літератури для дітей від давнини до сучасності. До локальних констант культурного поля субетнічного походження вчена відносить різноманітні складові (природні, культурно-мистецькі, соціально-історичні та ін.), що позначені карпатським колоритом [7, c. 195]. Д. Іваницька у праці «Дитяча книга Галичини» дослідила особливості видання книг для дітей у цьому регіоні [2]. У статті Н. Мельник «Криворіжжя і сучасна дитяча література» значну увагу приділено розгляду тематики та ідейного змісту літератури для дітей рідного краю [4]. Синтетичних досліджень, що були б спеціально присвячені вивченню регіональних змістових особливостей дитячої літератури Криворіжжя, ще немає.

Мета статті полягає в тому, щоб з'ясувати особливості моделювання художньої картини світу криворізького регіону у різножанровій літературі Криворіжжя для дітей дошкільного та молодшого шкільного віку, виявити маркери, що репрезентують їі регіональну детермінацію.

Виклад основного матеріалу. Різножанрова та змістовно багата дитяча література Криворіжжя має значний виховний та культурологічний потенціал. Вона виконує розважальну, естетичну, інформативну та пізнавальну функції. Твори для дітей сприяють соціалізації, формуванню ціннісних установок та розвитку творчого мислення юних читачів.

Збірочки поезій для дітей дошкільного та молодшого шкільного віку І. Доленник «Гойдалки», Н. Йолкіної «Ясне сонечко», М. Олексієнка 
«На баштані», «Я люблю всі пори року», М. Скиби «Отаке в нас киценя» та інші сприяють орієнтації юного читача в предметнопросторовому середовищі, містять інформацію про моральні норми та правила поведінки. Твори цих авторів у доступній для дитячого сприйняття формі передають знання про навколишній світ, явища природи, формують уявлення про красу, добро, дружбу, чесність та ін.

Короткі віршики Н. Йолкіної містять інформацію про пори року, родинні стосунки, світ професій та ін. У краєзнавчому аспекті вагомим $\epsilon$ те, що в збірочці вміщено інформацію про професію шахтаря. У творі «Шахтарем я хочу стати» в доступній для дошкільнят формі відбито прагнення ліричного суб'єкта до майбутньої професійної діяльності, пов'язаної з виконанням підземних робіт із видобутку залізної руди:

Шахтарем я хочу стати,

Руду з глибин добувати.

Щоб пишалась мною мати, Героєм Праці хочу стати [3, с. 69].

Соціоекономічна специфіка розвитку регіону обумовила широке розповсюдження професії шахтаря. Формування позитивного ставлення до цього фаху в мешканців краю розпочинається ще в дитинстві.

Історико-краєзнавче видання «Руднича азбука початку XX століття» I. Рукавіцина має всі ознаки традиційної абетки (містить алфавіт, опорні слова та малюнки до кожної літери), проте адресоване дітям середнього шкільного віку. Ця книга знайомить юного читача з Криворіжжям як одним із найпотужніших у світі залізорудних басейнів. Тексти та коментарі містять інформацію про особливості рудничної справи початку XX століття, а малюнки та фотокартки демонструють процеси видобутку залізної руди, корисні копалини регіону та знаряддя праці. До кожної літери наведено слова гірницької тематичної групи. Зокрема, до букви «Л» подано: «лампова, лампи, лампівник, лом, лопата, лебідка, лабрадорит» $[6$, с. 41$]$, а до букви «Р»- «рудокоп, рейок, рулетка, рукавиці, родоніт» [6, с. 49].

Для дітей дошкільного та молодшого шкільного віку працює творчий колектив (письменник М. Олексієнко та художник В. Журба) із селища Широке. Творчо-моделювальні видання «Робінзон», «Рябеньке поросятко» поряд із текстом містять розмальовки. Зміст книг формує в дітей усвідомлення єдності зі світом природи, повагу до старших, працьовитість.

У поезії «На баштані» враховано схильність дошкільнят до анімізму. Одухотворення природи (через надання неживим предметам, рослинам 
здатності думати, рухатись, відчувати) характерно для мислення дітей 4-5 років. Тому рядки, в яких передано ранкове пробудження родини кавунів, викликатимуть у дітвори відчуття емпатії:

\section{У ранковому тумані \\ Кавуни сплять на баштані: \\ Здоровенний лежить тато, \\ Поруч мама, сестри з братом. \\ Кавуняча вся рідня. \\ Не проснулась ще, куня [5, с.5].}

Із оповідок дідуся вимальовується топонімічна картина села. Юний читач дізнається про просторові межі баштану (території, на якій вирощують теплолюбні кавуни, гарбузи, дині). У текст уведено гідронім - назву річки Інгулець («B нашім славнім Інгульці» [5, с. 47]).

Зі збірочки Л. Челнокової «Ящірка Зі» юні читачі отримують уяву про багатогранність навколишнього світу, розмаїття видів тварин, їх поведінкові особливості. У творі «Мандрівниця» йдеться про домашню кицьку, яка повернулася з прогулянки відвалами, де «...камінчики pyдi $У$ калюжсах, у водi» [8, с. 11], що призвело до трансформації кольору шерсті від білого до рудого: «Бо руді у неї лапи, Спина вся - неначе мапа. Хвіст пухнастий теж рудий» [8, с.11]. У вірші письменниця знайомить читача з особливостями криворізького краю, де понад двісті років видобувають залізну руду. У результаті такої діяльності виникають порожні породи, які утворюють штучні насипи, схожі на гори. Антропогенні ландшафти краю містять гірничопромислові споруди, шляхи, кар'єри, канали тощо. Інформацію топоніма Кривий Ріг передано за допомогою інверсії «в руді залізній» та повтору колористичного епітета «рудий». Ця колороназва увиразнює особливості місцевих індустріальних пейзажів, які поблизу залізорудних шахт, кар'єрів, гірничо-збагачувальних комбінатів, шламосховищ набувають червоних відтінків.

У поезї «Криворізький горобець», що має діалогічну структуру, зображено зустріч птахів із Полісся та Криворіжжя. Із метою художнього відображення мелодійної орнітології у творі вжито звуконаслідувальне дієслово «ивірінчати» [9, с. 229]. Під час пташиної комунікації обговорюється хроматична колористична гама оперення криворізького горобця:

Чом ти, друже, рудуватий?

Модно пір'я фарбувати? 
134Літератури світу: поетика, ментальність і духовністъ. 2020. Вип. 14

Ми отут, серед природи,
Щось відстаємо від моди...»
Запишався рудокрилий:
«Де б такого ви зустріли?
Досі ж в гостях не бували
там, де шахти та відвали!..
Я фарбований водою
Із залізною рудою.
Є в одному тільки місті
Горобиі такі барвисті $[9$, с. 229$]$.

Рудий колір у дитячих творах Л. Челнокової виступає своєрідним образно-асоціативним символом краю. Перцепція колоративів у поезії письменниці не обмежується їхнім лексичним значенням, вагомими стають асоціації, які пов'язані із залізорудною промисловістю. Як стверджує Н. Яременко, наявність у художньому творі «колористичного образу активізуе тонкий почуттевий нюанс» [11, с. 156].

Збірка оповідань «Джерела рідної землі» В. Білоуса своїм змістом заохочує читачів до пізнання історії міста. Твори орієнтовані на учнів середнього та старшого шкільного віку. Підзаголовок «Оповідання про Дубову Балку» виконує просторово-орієнтаційну функцію. Передмова книги містить інформацію про розвиток залізорудної промисловості в регіоні, дослідження з історії розробки корисних копалин у Великій Дубовій Балці. Як відзначає Н. Мельник, автор дотримується версії, що саме в цьому місці «заховані незліченні скарби гетьмана Павла Полуботка, розповідае про результати археологічних відкриттів на иій територї та висвітлюе діяльність відомих істориків Олександра Поля та Дмитра Яворницького в плані дослідження Криворіжжя» [4, с.211-212]. Мікротопонім Дубова Балка відомий переважно місцевим жителям, проте має важливе історичне значення. Ця територія пов'язана з початком промислового видобутку залізної руди в місті. Просторовою домінантою оповідань є гідроніми Саксагань та Інгулець, мікротопоніми Вечірній Кут та Велика Дубова Балка.

Застосовуючи ретроспекцію, письменник відтворює цю місцевість як ремісничий центр «<..> у Європі з видобутку й переробки залізної pyдu» $[1$, с. 9]. Використання елементів фантастики дозволило автору охопити різні часові площини (від епохи палеоліту до сучасності). В. Білоус відтворює далекі часи, коли люди послуговувалися запасами болотної залізної руди: «Місц,ями руда глина просто скам'яніла $i$ тепер нагадувала черепки здоровенних битих горщиків. Через тисячі 
років потому таким запеченим черепкам рудої глини (залізної руди), змішаної з окислювачами, дадуть назву агломерату, $i$ з нвого будуть виплавляти в доменних печах чавун» [1, с.25]. Подібний ракурс зображення рідного міста сприяє формуванню історичної пам'яті, соціалізації молодого покоління.

Висновки. Сучасна література Криворіжжя для дітей дошкільного та молодшого шкільного віку органічно входить у загальний простір української культури. У художніх творах митців регіону змодельовано картину дійсності, що сприяє адаптації реципієнтів до навколишнього світу, відтворено специфіку мислення та поведінки дітей, передано особливі форми комунікації в колективах певних вікових груп. Образна система творів та їх тематика адаптовані до сприйняття читачами певної вікової категорії.

У дитячій літературі Криворіжжя значну інформаційну роль відіграють регіональні маркери, уведення яких дозволило авторам сформувати художню картину світу, що репрезентує особливості металургійно-гірничого краю. Територіальні, професійні, соціокультурні концептосфери увиразнюють цей аспект. В основі регіональної ідентичності Криворіжжя, що об'єднує часові площини минулого та сучасного, лежить погляд на край як промисловий центр, один із найпотужніших залізорудних басейнів країни.

У творах присутні маркери на позначення своєрідності місцевості: гідроніми, назви корисних копалин, описи ландшафтних особливостей, інформація про металургійно-гірничі професії тощо. Уведення цих смислових моделей у художню палітру дитячої літератури сприяє формуванню у свідомості юних читачів відчуття власної регіональної приналежності.

Уважаємо, що твори літератури Криворіжжя для дітей дошкільного та молодшого шкільного віку в майбутньому можуть стати об'єктом дослідження їх з точки зору національно-патріотичного виховання.

\section{Література}

1. Білоус В. Джерела рідної землі : оповідання про Дубову Балку. Кривий Ріг : Видавничий дім, 2006. 88 с.

2. Іваницька Д. Дитяча книга Галичини. Вісник Книжкової палати. 2010. № 8. С. 29-33.

3. Йолкіна Н. Ясне сонечко. Кривий Ріг : СТПРЕС, 2016. 88 с.

4. Мельник Н. Криворіжжя і сучасна дитяча література. Філологічні студії. Науковий вісник Криворізького державного педагогічного 
136Літератури світу: поетика, ментальність і духовністъ. 2020. Bип. 14

університету : збірник наукових праць. Кривий Ріг : Центр-Принт, 2012. Вип. 7 (2). С. 205-215.

5. Олексієнко М., Журба В. На баштані. Кривий Ріг : Видавничий дім, 2006. $64 \mathrm{c.}$

6. Рукавицын И. Рудничная азбука начала XX века. Киев : АртТехнология, 2015. 64 с.

7. Ходанич Л. Виховний потенціал дитячої літератури Закарпаття. Ужгород : Інформаційно-видавничий центр ЗІППО, 2010. 208 с.

8. Челнокова Л. Ящірка Зі. Вірші. Оповідання. Казки. Кривий Ріг : Саксагань, 2002. 80 c.

9. Челнокова Л. Поезії. Символ : культурологічний альманах. Кривий Ріг : Діоніс, 2017. Вип. 5. С. 226-227.

10. Яковлєв О. Трансформація регіональних ідентичностей в сучасній Україні. Актуальні проблеми історії, теорії та практики художньої культури : збірник наукових праць. Київ : Міленіум, 2013. Вип. 30. C. $110-117$.

11. Яременко Н. Настрій тексту як складова ефекту присутності в повісті О. Чупи «Вишня і Я». Літератури світу: поетика, ментальність і духовність. Кривий Ріг, 2018. Вип. 12. С. 150-158. 